\title{
Australia and the Birth of Israel: Midwife or Abortionist*
}

Howard Adelman

The tiny Republic, which embodied the age-old dreams of world Jewry and militant Zionism, was bom in 1948 with Evatt as midwife.

\section{Introduction}

When the First Committee of the Special Session of the United Nations convened on 6 May 1947, they had before them the 2 April request, of Sir Alexander Cadogan of the United Kingdom, to place the question of Palestine on the Agenda and "to make recommendations, under Article 10 of the Charter, concerning the future government of Palestine". ${ }^{1}$ In order to expedite the process, Cadogan requested the Secretary-General to convene a special session of the General Assembly to constitute and instruct a Special Committee to prepare a report for the General Assembly. The Committee became known as UNSCOP.

UNSCOP consisted of eleven "neutral" countries - two Commonwealth nations (Canada and Australia), two Eastern European nations (Czechoslovakia and Yugoslavia), three Latin American countries (Guatemala, Peru and Uruguay), two Asian nations (India and Iran) and two Western European nations (Sweden and the Netherlands). UNSCOP recommended partition by a vote of seven for, three against (they wrote a minority report supporting a federal solution), and one abstention - Australia.

Using that report, a special Ad Hoc Committee chaired by the Rt Honourable Dr H. V. Evatt, then Deputy Prime Minister of Australia, Attorney-General and Minister for External Affairs, as well as Chairman of the Australian Delegation to the UN, recommended partition to the General Assembly. In the alphabetic roll call on the vote in the Ad Hoc Committee, even though Australia held the Chair, Australia cast the first yea vote for partition after Afghanistan voted against and Argentina abstained. On 29 November 1947, the United Nations General Assembly voted by more than a two-thirds majority to support partition.

Evatt was showered with cables and telegrams from Jewish organisations in Palestine. ${ }^{2}$ Evatt describes how, after the partition vote in the United Nations, the Jewish people and their supporters' "display of gratitude towards myself was most touching". Evatt went on to say, with uncharacteristic modesty, that "I had only done what I believed was just and right as a good United Nations follower" ${ }^{3}$ Between that declaration of the UN and the date when Israel was born on 15 May 1948, Evatt was regarded as one of the champions of Israel. He fought attempts by the USA and the UK to reverse the pro-partition

* Special thanks are due to Ms Gillian Redmond and the other staff of the National Archives of Australia in Canberra without whose extraordinary efforts I would not have obtained access to previously closed files. 
resolution and substitute a UN trusteeship. "I could not leave Australia at that time but I sent a message which was broadcast throughout the world with the object of making it clear that the proposed trusteeship plan was not only inadmissible and indefensible in itself, but represented a complete setting aside of the decision of the previous Assembly." 4 He advocated that the Security Council intervene with force to stop the Arab invasion. In January 1948 under Evatt's leadership and inspiration, Australia was the first government to give de jure, that is, full recognition, and not just de facto recognition to the new state of Israel.

Evatt was considered strongly pro-Zionist. ${ }^{5}$ He had close connections with the Jewish business community in Australia. 6 Though the only Jewish parliamentarians in Australia at the time were on the Right, "Labor gained support (from Jewish voters) through Dr. Evatt's key role at the United Nations in the establishment of Israel". ${ }^{7}$ Evatt was credited with being one of the most important foreign statesmen in the creation of Israel. He can even be said to have been a midwife at Israel's birth. Evatt "chalked up the birth of the State of Israel to his credit as chairman of the United Nations ad hoc committee on Palestine. The tiny Republic, which embodied the age-old dreams of world Jewry and militant Zionism, was born in 1948 with Evatt as midwife. Great was the acclaim he received from Jewish people at home and abroad. When he attended functions in his honour given by Jewish organizations, he was always sure of the nearest thing in Australia to a hero's welcome."8

However, very little has been written about Evatt's role on the substantive issues at stake when the matter was first put before the United Nations and when it was considered in UNSCOP. Chapter X of his book, The Task of Nations, deals with the first phase of UN involvement in the Palestine issue in the setting up of UNSCOP. Other than crediting Australia with "the initiative at the General Assembly in the appointment of UNSCOP"9 and the initiative in keeping the five great powers from being members of UNSCOP, the main thrust of Evatt's own account is concerned to convey the impression that he acted as an exemplary impartial chairman of the proceedings of the Ad Hoc Committee dealing with the UNSCOP report while, at the same time, being resolute in ensuring that the work of the committec moved expeditiously and made a decision. "In its handling of the Palestine dispute ... [Evatt] felt the Assembly had approached the problem not on the basis of expediency but impartially and solely in terms of the best interest of the inhabitants."10

Evatt does comment critically on the minority report of UNSCOP recommending a federal state. "In the legislature of this state, representation would have been given to Arabs as well as Jews, but inasmuch as the Arabs outnumbered the Jews, the Jews would have had no effective control within any portion of the proposed state. Migration of the Jews could, and no doubt would, have been terminated or been drastically restricted by the Arab majority with the result that the Jews would have become a permanent minority in Palestine with serious repercussions, and disaster to all their hopes of national survival."11 But it is unclear when he made this evaluation. For he states clearly that when he assumed the role of Chairman of the Ad Hoc Committee, "I entered upon the work of the Committee without prejudices in favour of any particular solution".12

Commentators have had little to say about Australia's abstention and Evatt's transformation from a purported neutral spectator to an ardent pro-Israel advocate. Allan Dalziel simply said that "Evatt worked for the establishment of the promised national home for the Jews and the creation of the autonomous State of Israel".13 Kylie Tennant wrote that Evatt "supported the cause of Israel because he felt the Jewish people were a race that must have a sanctuary". ${ }^{14}$ In Alan Renouf's political biography, Let Justice Be Done: The Foreign Policy of Dr. H. V. Evatt, his role is summarised in one paragraph: 
No better testimony exists to Evatt's pursuit of justice than the part he played in the establishment of the State of Israel. When Britain referred the Palestine problem to the General Assembly in April 1947, Evatt was instrumental in having the Assembly set up a committee of investigation. Australia was a member. In August the committee produced two reports: the majority report recommended partition into two independent states, one Arab, one Jewish; the minority report, one federated state. Australia supported neither solution. The General Assembly appointed another committee to examine the reports. Evatt was chairman. In this committee, Evatt came out for partition, and a plan for it was prepared, which the General Assembly approved on 29 November. 15

The paragraph is more puzzling than insightful. On the one hand, it makes no reference to the British view, articulated by the Colonial Secretary, Arthur Creech-Jones, ${ }^{16}$ that the major factor which scuppered the British strategy and led the UN to endorse partition was Evatt's decision as Chair of the Ad Hoc Committee on the Palestinian Question in the autumn to work, on the one hand, in two separate committees. One was pro-partition and one anti-, without any real effort at the same time at conciliation between the Arabs and the Jews in the third committee. The charge was that the very committee structure he set up mitigated against conciliation. The American State Department concurred in the British view of Evatt's failure to work for conciliation. Samuel K. C. Kopper of the Office of Near Eastern and African Affairs noted that "the abortive and utterly weak efforts of Dr. Evatt to bring conciliation to bear during the General Assembly session can hardly be classed as United Nations conciliation".17

On the other hand, Renouf provides no reason why Australia abstained in the UNSCOP major recommendation on partition, and then why Australia subsequently supported partition and Evatt became renowned as a champion of the Israeli cause. Furthermore why in the autumn of 1949, when a major diplomatic attack was made on Israel's jurisdiction over Jerusalem, did Dr Evatt, virtually to everyone's surprise at the behaviour of someone regarded as strongly pro-Israel, as one of his last acts as an international statesman, support the campaign to reaffirm the UN resolution on internationalisation? Abba Eban, liaison officer of the Jewish Agency to UNSCOP at the time and later Israel's ambassador to the UN and Foreign Minister, wrote that "We were never able to diagnose the cause for Herbert Evatt's strange obduracy in this matter". 18 Was Evatt just an unpredictable person as the Americans believed? 19

The reasons why Evatt was greeted as a champion of Israel are not hard to find. Evatt was almost certainly Australia's most brilliant Extemal Affairs Minister. He was intelligent, ambitious, authoritative and a very assertive politician. He reigned supreme over Australia's foreign policy in the World War II and immediate post-World War II period and was the crucial figure in establishing Australia as a principal independent player in the international arena no longer tied to the apron strings of Mother Britain. 20 Allan Dalziel, his secretary for twenty years, portrays Evatt as the "defender of human rights and dignity" who was never "devious or ambiguous, conspiratorial or laodicean" but earned "enmity through nonconformity". 21

Not all portraits of Evatt are so flattering. Abba Eban, with his usual sharp tongue, said of Evatt that, "His self-confidence was absolute. Behind his abrasive exterior lurked an abrasive interior. He never allowed his resolution to be blunted by any confession of fallibility".22 Brian Urquhart, a career civil servant at the UN, was even more scathing. After describing Evatt as "unpredictable, ambitious, and later on an almost paranoid President of the General Assembly", 23 he went on to say that "Evatt was a brilliant but insecure man, almost paranoid in his desire to dominate and in his suspicion of those around him. He was even jealous of Eleanor Roosevelt". ${ }^{24}$ Michael Comay, who headed the Israeli team at the UN, also considered that Evatt was insecure and had a weak ego. Comay believed that in May 1947 his flattery of Evatt and of his importance in the debate 
had obtained Australia's commitment to support partition, even while he carried on a pretence of impartiality to advance his own career. ${ }^{25}$

Evatt's role as a champion of Israel emerged because he applied his brain, political skills and determination as Chairman of the Ad Hoc Committee of the General Assembly and ushered through the manoeuverings and the debate that culminated in that historic vote on 29 November 1947 which recommended the partition of Palestine and the creation of a Jewish state. He also committed Australia's vote to support partition. As Evatt noted on 25 November 1947, "abstention in the vote is the worst course to follow as it would tend to lead to a situation of abdicated responsibility on the part of the United Nations".26

Renouf explains Evatt's commitment to Israel as follows:

The issue was close to Evatt's heart. Near associates record him as saying, as early as September 1945, that the Jewish people had to have a permanent home, where they could live in dignity and self-respect, and that they had full historical rights in Palestine. If the Arabs refused it, the United Nations had to decree and guarantee it. The explanation for Evatt's attitude is justice. Aware of the Jews' sufferings, he tried to create the conditions where those sufferings would not recur. He led the investigation by the United Nations which suggested that there should be a Jewish state within Palestine; for Evatt there was, therefore, no alternative but to have the state established. 27

Though Renouf says. Evatt "led the investigation" he is, in fact, referring to the Ad Hoc Committee of the General Assembly, rather than UNSCOP, the investigating committee. The real question is why did Australia abstain on the partition recommendation by UNSCOP? Did John Hood, the career external affairs officer appointed to UNSCOP, act independently of government direction, as, in fact, did most of the other members of the Committee as they were expected to do? Not according to Evatt.

I had always insisted, right from the first meeting of the Security Council in London of 1946, that where there were disputed questions before a United Nations body, a proper foundation or basis for any recommendation must be discovered. It was therefore essential that the relevant facts should be declared authoritatively after the fullest investigation by an impartial committee or commission. We had also contended that full publicity must be given to all the findings of any such committees or commission.

Australia's point of view was pressed forward repeatedly with Security Council disputes in relation to Iran, Greece and many other subjects. The practice of enquiry and investigation had become fairly well settled.

Accordingly when Australia was elected to UNSCOP our delegates, John Hood and S. L. Atyeo, joined in the full report of the facts without committing Australia at the time to any firm decision in relation to the majority and minority recommendation of UNSCOP. 28

Two points are noteworthy. One, Evatt clearly implies that the Australian delegates voted according to Australian policy. Second, the rationale for abstention is given as the policy of investigating bodies having the responsibility for ascertaining the facts and, presumably, not making recommendations when there was a dispute over facts or recommendations that stemmed from the analysis of those facts. Thus, although Austraila led the fight in San Francisco against the Yalta voting formula which allowed any one of the five great powers a veto in the Security Council, in the final vote Australia abstained. ${ }^{29}$ Australia was also a member of the United Nations Special Committee on the Balkans (UNSCOB). "The Australian representatives ... dissented or abstained from categorical conclusions based on the presumption of observers." 30 When in October 1949, the First Committee of the General Assembly called upon the President of the General 
Assembly to negotiate with the Greek govemment suspension of death sentences imposed on eight individuals convicted of "political" offences, Australia abstained. ${ }^{31}$

But there are explanations for these and other abstentions other than ones of procedural principle. On the issue of the veto, it might have meant no Charter and no United Nations if Australia won. On the issue of Albanian, Bulgarian and Yugoslavian support for Greek guerrillas, the rationale for abstention was not attributed to lack of unanimity but to the drawing of categorical conclusions of fact on the basis of scanty evidence. On the Greek issue of the condemned political prisoners, "Australia's abstention may have arisen out of anxiety at the action of the Greek government without any intention of creating a precedent for intervention". 32 And the principle of limiting UN jurisdiction $v i s-a-v i s$ domestic issues was critical to Australia. In other words, wherever there was an abstention on the procedural principle, there seemed to be a substantive motive for Australia's abstention. Alternatively, a different procedural principle (related to evidential support, for example) was operative. What was the underlying basis for the abstention in UNSCOP if there was one?

Firstly, the abstention has no basis with respect to the restricted terms of reference to which Evatt referred. Though clause 2 of the Terms of Reference states that, "The special committee shall have the widest powers to ascertain and record facts, and to investigate all questions and issues relevant to the problem of Palestine", clause 6 makes it perfectly clear that UNSCOP was not just a fact-finding mission. "The special committee shall prepare a report to the General Assembly and shall submit such proposals as it may consider appropriate for the solution of the problem of Palestine." 33 How unusual and unexpected that abstention was can be gathered from the comments of other members of UNSCOP. For example, Nicolaas Blom, the Dutch representative on UNSCOP, a civil servant in the Dutch Foreign Office, and the one other delegate taking direct orders from his Ministry, referred to the Australian abstention as "incomprehensible" and "not greatly appreciated".

Wellicht moet uit de voormelde onzekerheden verklaard worden de houding aangenomen door de Australische gedelegeerde, die zich geheel heeft onthouden van het uitspreken van een ordeel. Dat deze houding onbegrijpelijk werd geacht en wenig wardering vond, behoeft geen betoog. Torecht, naar mijn oordeel, waren alle leden van de Commissie van mening dat de Verenigde Volken, welke aan de Commissie deze odpracht gaven, mochten verwachten, dat de leden zich niet aan het uitspreken van een inzicht zouden onttrekken. ${ }^{34}$

But couldn't Hood have voted in the committee independently of Australian and, more particularly, Evatt's policy? As Allan Dalziel described it, "John Hood, and other senior officers like Dr. Anstey Wynes, never seemed to be at home with the Evatt brand of bustling diplomacy". ${ }^{35}$ But if Hood voted contrary to Evatt's wishes, why then would Evatt, who saw to it that he was head of the UN delegation, appoint someone who would deviate, not only from Evatt's deep commitments, but from the majority of the members of the committee? Why would Evatt subsequently keep promoting Hood? In any case, Evatt said Hood was following the policy as set down by the Australian delegation, i.e., Evatt. Does the role the Australian delegate played in UNSCOP clarify whether Evatt was driven by expediency or was motivated by a passion for justice?

Dr John Burton, appointed by Evatt as Secretary of the Department of External Affairs, accused Evatt of duplicity. "In 1947 Evatt allegedly started to abandon principle in policy for expediency." 36 Renouf, after all his research and his own close personal service to Evatt, was unconvinced. Justice, not expediency, drove Evatt.

After the vote, as head of the UN delegation during a crucial period, Evatt led the battle against the UK and US State Department team attempt to push through a trusteeship proposal and reverse the UN position on partition. ${ }^{37}$ On 8 April 1948, he issued an 
instruction to John Hood, departmental head of the UN missionm, as follows: "the Assembly decision was based on on-the-spot investigations by the United Nations and exhaustive discussion during the Assembly. The United Nations cannot lightly set aside a decision adopted by two-thirds of its members. Before, therefore, the Special Assembly agrees to reconsider its decision, those sponsoring reconsideration must give cogent reasons, and the Special Assembly, which is in control of its own business, must then decide whether in fact it will reconsider the decision." $38 \mathrm{He}$ went on to argue that there were "no cogent reasons for reconsideration". Trusteeship, he concluded, "will not be considered to offer a real solution".

Evatt led the charge in the First Political Committee and the Fourth Trusteeship Committee in opposition to the high powered cabal of the State Department of the USA, the UK and France which was then trying to reverse the partition decision. Even Canada capitulated and supported trusteeship. ${ }^{39}$ Though it was eventually dropped, Australia sponsored a rival resolution to reaffirm partition. Australia could not see why any thought should be given to interfering with partition, "especially as the authority and credit of the United Nations was involved". 40

Evatt, it must be remembered, was one of the visionaries of and architects behind the trusteeship system. 41 His support for trusteeship was bounded by two principles. "The first was his refusal to go any further than self-government as the end goal of trusteeship. The second was his insistence on no interference with the sovereignty of the countries to hold trusteeship." 42 Evatt had argued for transferring mandates to trusteeships at San Francisco, but without granting sovereignty. Why had he now changed his mind and instead demanded independence and opposed trusteeship?

Evatt's championship seemed brave but also foolhardy. For he coveted the Presidency of the General Assembly (a fact which was well known), and just lost out at the beginning of the current session. ${ }^{43}$ His stand on partition risked alienating the pro-Arab vote for that reason alone. But he went further and advocated the use of force by the Security Council against the Arabs. That position risked alienating the Americans as well as the Arabs. He worked assiduously to get the Security Council to take up the issue of Palestine prior to the 15 May 1948 deadline so that the Security Council could declare a threat to peace and adopt coercive measures to prevent or inhibit an Arab invasion of Palestine after 15 May. One draft resolution prepared by the Australian delegation called upon "the Arab states to cease their defiance of the clearly stated intentions of the majority of the members of the United Nations". Another draft included this passage: "DRAWS THE ATTENTION of the Security Council to what must clearly be regarded as a threat to international peace and security, and earnestly requests it to take such action under Chapter VII of the United Nations Charter as might remove or alleviate this threat". The same draft called upon "the Security Council to impose economic sanctions on Arab countries which send forces into Palestine". 44 However, Australia ended up as one of the leaders of the rearguard action to prevent the UN from backsliding on its decision; there was no real opportunity, or realistic prospect, to advance the principle contained in the United Nations Charter whereby the United Nations would act collectively to repel aggression. Nevertheless, at the beginning of May 1948, he advised Truman (contrary to the known policy of the US, both against the involvement of its own forces and an even stronger opposition to any military involvement of the USSR in the Middle East) to lead the intervention of the Great Powers in the Palestine conflict. Truman thought his suggestion was preposterous. ${ }^{45}$

Evatt had championed the trusteeship system without any entailment of sovereignty. Now he opposed trusteeship and pushed independence. Evatt was critical of the role of the Great Powers, particularly the US and the UK, but now advocated their intervention in the Middle East. Australia had abstained in UNSCOP and now had become one of the most 
ardent supporters of partition. The last line of the report of the Australian delegation on the whole debate stated that, adopting partition "was the only possible course that could be taken and the only one consonant with the proper authority and dignity of the United Nations". ${ }^{46}$ How does one explain all these apparent inconsistencies?

\section{UNSCOP}

Australia had not always given evidence of being an active champion of the Zionist cause. Quite the reverse. When the United Nations had been called into special session in the spring of 1947 to deal with its first major crisis - Palestine - Australia was a very cooperative partner for the British in preventing the movement of illegal immigrants to Palestine. Australia went so far as to refuse to issue passports to its own citizens if their destination was Palestine and they had not received prior approval from the British to travel to Palestine. In a memo dated 24 June 1947 from the Department of Immigration to the Department of External Affairs in Canberra, it was noted that "facilities for travel to Palestine (will only be granted) where it is clear that applicants are eligible to enter that country in accordance with Palestine immigration regulations. In cases of doubt it is the invariable rule to make prior reference to the Commissioner for Immigration, Jerusalem, and to withhold the grant of passport facilities unless and until advice is received from that official that an intending traveller will be permitted to land."47

Nor could Evatt be said to be unaware of this policy. In fact the UK had sent a special letter to Dr H. V. Evatt, Minister of State for External Affairs in Canberra, to do "all in their power to discourage illegal immigration while the question remains sub judice". 48 Evatt may even have been the architect of the policy.

However, Australia's cooperation with Britain and lack of sympathy with the Zionist cause was much more home grown than simply the product of a compliant ex-colony doing the mother country's bidding. This became clear in Australia's initial role on UNSCOP. Australia had won its place on UNSCOP by only one vote over the Philippines. The vote was 21 to 20. This was in spite of the fact that Australia campaigned to win the appointment (in contrast to Canada or the Netherlands, both of which had been reluctant to take on that role). In fact, in a ministerial memo dated 22 April 1947, it was declared that the "main purpose of Australian participation in session is to secure for this country a place on the body to report to the regular session". 49 The marginal support may have been the result of a perception by other delegates that Australia would serve as a ringer for the UK.

UNSCOP was charged with studying the situation and bringing back recommendations to the United Nations Special Assembly so that it could determine a course of action. "The primary function of the committee was to ascertain the facts and make a recommendation to the regular General Assembly." 50 In the final report of UNSCOP tabled at the beginning of September of 1947, other than supporting the unanimous recommendations calling for an end to the Mandate and the granting of independence to the peoples of Palestine, the Australian delegate, John Hood, neither supported the majority recommendation for partition backed by the seven delegates from Sweden, Canada, Uruguay, Peru, Guatemala, the Netherlands and Czechoslovakia, nor the minority recommendation of India, Iran and Yugosiavia for a Federal State. The Australian abstained.

This abstention could have had grave consequences. For the divisions in the committee were much greater than they even appeared in the final report. The Dutch delegate, Dr Nicolaas Blom, like Hood, and unlike many of the others who were judges or politicians, 
was a career civil servant. He had spent most of his life as a colonial administrator in Indonesia. He and Hood seemed to share an affinity in the UNSCOP committee in their methodological and unassuming approach to issues. Both played their cards very close to their respective chests. David Bercuson drew the same conclusion I did after reading the minutes of UNSCOP that John Hood "took great pains, during his tenure at UNSCOP, not to reveal to his fellow committee members his innermost impressions or thoughts on the issue at hand".51 Neither took the lead in most of the discussions. But when the committee - armed with the rationale that part of its terms of reference called for the parties to the conflict to desist from acts of violence while the Committee was doing its work appeared to them to be veering off course when it decided to complain to the British against the British decision to hang three convicted Irgun terrorists, Hood and Blom joined together to protest strongly. They believed this was a gross deviation from the terms of reference of the Committee and an interference with those charged with the administration of the Mandate.

This pro-British stance was in sharp contrast to the original worries the British had about Hood. "Australian Delegation have received instructions to press strongly for Australian representation and Australian Government have indicated to their delegation that Hood would be their choice ..." and it would, therefore, be "useful to United Kingdom Delegation to have some indication from Windle as to Hood's suitability in light of Balkan Commission's experience".52

Blom had clear instructions from the Dutch foreign office to avoid alienating the Arabs as the Dutch needed their support to retain control over Indonesia. ${ }^{53}$ It was only when it was clear that the evidence overwhelmingly favoured partition, and that there was a clear majority in favour of partition, that the Dutch delegate was permitted by the Foreign Office to commit his vote to support the majority recommendation. But Hood had no inkling of the Dutch instruction, though he did sense Dutch opposition to partition in early August ${ }^{54}$ The reluctance of the Dutch to confide in the Australians was probably rooted in a combination of diplomatic reserve and the conviction that Evatt and Australia were hostile to the interests of the Netherlands in Indonesia. 55 Fighting had broken out between the Dutch government and the indigenous population of Java and Sumatra on 20 July 1947. On 30 July it was Australia that brought the issue before the UN Security Council which Holland declared to be interference in its domestic jurisdiction. The mutual suspicion of Holland and Australia meant that Hood and Blom, in spite of or because of similar civil servant styles and subservience to their ministries, were not able to collaborate.

Everyone knew the Peruvian delegate would vote any way as long as the Vatican was satisfied and the Holy places were secured from the Muslim and Jewish factions by an international jurisdiction. Dr Arturo Garcia Salazar, a devout Catholic, was Peru's ambassador to the Vatican. "His religious views coloured his approach to the Palestine question and inclined him to concentrate on the issue of Jerusalem and the holy places more than any other aspect of the problem".56 If the Peruvian and the Dutch defected from the majority, there would be only five for partition and five against. Hood, the Australian would have had the deciding vote.

Who was Hood and why did he abstain in the UNSCOP committee?

\section{John Hood}

John Hood was a career civil servant who joined the Department of External Affairs six months after his twin daughters, Catherine Bridget and Anna Elisabeth, were bom. He 
was assigned to Australia House in April 1936. He finished his probationary period on 14 October 1936 and received his first promotion in April 1937, one year after he joined the department. Hood was appointed Officer-in-Charge of Political Section in Canberra, received another rise, and returned to Australia after 15 December 1938.

Hood was not very useful to his political masters in predicting the ensuing conflagration. In that he shared the predominant isolationist and appeasement attitudes that dominated Australian perceptions, particularly those of the Labour party. On 26 May 1939. Hood welcomed Halifax's recent statement on Anglo-German relations and supported the Chamberlain strategy. Evatt was far more prescient for he wamed Australians about the gathering storm clouds. Hood was also mistaken in a number of specifics. He thought that a Soviet-German pact was impossible. On 14 June 1939 he wrote a departmental memo stating that he was "doubtful about the military value of Russia, and I have never regarded as serious the possibility of an arrangement being arrived at by Germany and the USSR".57 As war became more and more imminent, Hood became more and more resistant to accepting the impending reality. "The Government has given no 'proof' of any sort of emergency and ... Australia has allowed itself to be caught up in a war scare which has no real foundation." 58

Nevertheless, in spite of these shortcomings as a prophet, he continued his rapid rise in the Department. And in spite of being totally at odds with Evatt about the coming war, during and after the war he moved closer to the centre of power. In 1945, John Hood, as the senior representative of the Department, along with Sam L. Atyeo - who would become the Australian alternate on UNSCOP - travelled with Evatt on a Special Mission to London via Jerusalem, a trip which began on 4 September 1945 after Evatt had returned from his triumph in San Francisco. 59 Whether the stop in Jerusalem had any relationship to the special mission, I was not able to learn.

Hood was very busy. Using London as a base, he went for six days to Paris, after being stranded for two days in Brussels, and then went on to The Hague to establish an Australian legation where he held "a roaming commission as charge d'affaires". $60 \mathrm{He}$ returned to London on 23 November only to set off again for Holland three days later and to Berlin on the 30th to establish a military mission. Hood was a member of the Australian Delegation to the Reparations Conference.

Hood subsequently took up his position as departmental head of the Australian delegation at the UN. He could only have attained that position in Evatt's beloved UN because Evatt had great trust that Hood would serve him well. Evatt was too dominating a personality to tolerate a strong minded wilful individual in the institution that was so close to his heart. Evatt did not choose Hood because of his brilliance as a political prognosticator. Hood was no more prescient at the UN than he had been in 1939. With respect to Palestine, he wrote in a widely shared conviction that the "probabilities are in favour of its [the USSR] supporting the Arab claims".61

Though Hood would go on to serve as Ambassador to Indonesia from 24 June 1950 to 26 February 1952,62 and from 1952 to 1958 served as Ambassador to Germany, following which he was appointed Director of Scientific Secretariat, International Atomic Energy Commission, and even became Ambassador to Israel, Hood's moment of international glory came when he was appointed to UNSCOP in April 1947. Abba Eban described Hood as "a professional diplomat whose sharp mind was concealed by an easygoing disposition and a very marked taste for conviviality".63 The department had recommended that Moore be appointed, ${ }^{64}$ but Evatt saw to it that Hood got the position. Atyeo, "Evatt's eyes and ears on the world", 65 was appointed as his alternate. Evatt now had his two most trusted lieutenants on a Commission that would make the critical recommendation on the future of Palestine. 


\section{Hood on UNSCOP}

Hood recognised what his role on UNSCOP was supposed to be, as his own memo attests. "The balance of the 11 members [were to] be selected on the basis of geographical distribution and neutrality on the issues." 66 Furthermore Evatt also knew that Hood was appointed as an independent member. On 24 May 1947, after Hood took up his position, the Australian Ambassador cabled to the Minister noting the Rand appointment by Canada and that in this case "it is not proposed to issue him any specific instructions". Canada's appointee was specifically instructed by Extemal Affairs Minister St Laurent (soon to become Prime Minister) "to act in an independent capacity"67 as much to preserve Canada's flexibility as to ensure that the "best possible person" would serve with distinction. "The Canadian representative has not been instructed by the Canadian government concerning the policy he is to advocate or support" $68 \mathrm{St}$ Laurent announced to the House of Commons on 22 May 1947. Wrong (the Canadian Ambassador to Washington) said that Rand was regarded as an able lawyer who had been a member of the Court for approximately three years. "Wrong also mentioned that the Swedish Government tended to follow the same course regarding instructions to its Representative on the Committee."69 Hood was not on the Special Committee to defend the interests or represent the views of Australia. Nevertheless, as we shall see, unlike Rand and Sandstrom, but like Bloom and Spitz of the Netherlands, ${ }^{70} \mathrm{Hood}$ and Atyeo received their instructions from the Department of External Affairs.

Hood's responsibility to act as an independent, neutral investigator was made clear in the terms of reference sent by the UN to the Australian delegation on 16 May 1947. They stated that "States Members of the Special Committee should appoint persons of high moral character and of recognised competence in International Affairs, and that those appointed would act impartially and conscientiously (emphasis added) in accordance with the purposes and principles of the Charter of the United Nations". ${ }^{71}$ Hood was not there to be a delegate representing the Department of External Affairs of Australia.

Hood was not only supposed to be independent, but UNSCOP was set up explicitly as a "neutral" committee. The neutrality was to be a product of its overall composition and not the lack of any predisposition of its members. Neutrality meant lack of prior stated commitments and an adherence to procedural fairness. It did not mean absence of bias.

A country or a representative would be considered partial: (a) if its delegate already expressed a prior commitment to one outcome or another; (b) if its existing commitments predetermined one outcome rather than another; or (c) if it had a vested interest in the outcome. The Arab states were clearly not neutral, and that is why their presence on the committee - supported by the Australian delegation - was rejected. ${ }^{72}$ Neither was the UK, but the Australian delegate was expected to be. And he was, insofar as he had never publicly expressed support for either the Jewish or the Arab positions. He was not neutral, however, in the sense that his commitments did rule out his voting in favour of the Zionist position. Australia did, as we shall see, have a vested interest in one outcome. In the case of Holland, that vested interest was based on the foreign policy concern with favouring the Arabs to win their support for the Dutch position on Indonesia. What was the vested interest of Australia?

There were four major concerns that would influence Hood's role in the Special Committee - his attitude to the Jews, the UK, the Arabs and his view of Australia. His attitude to the Jews can be discerned from the fact that he (and Sir Abdur Rahman of India as well as Bloom and Spitz of Holland) ${ }^{73}$ opposed going to visit Displaced Persons (DP) Camps that held the Jewish DPs in Europe. ${ }^{74}$ Perhaps because of that opposition, he was 
chosen to head the subcommittee of UNSCOP that visited the camps. Although he cabled his department with up-to-date reports on the proceedings of UNSCOP, there is not one word in the files about his visit to the camps, a response that stands in marked contrast to the powerful impression the visit made on the other members of his subcommittee. This silence is also in stark contrast to Abba Eban's conviction (with no evidence cited) that, "I had also noticed a positive change in John Hood's attitude since his traumatic contact with the displaced persons in the European camps". ${ }^{75}$ Did Abba Eban have any evidence?

Hood was certainly unsympathetic to the creation of a Jewish State in Palestine as his early report to the Department on UNSCOP attests. He "considered that the claims for immediate independence and for a Jewish State to be founded by accelerated migration over the next few years were equally unreal and offered little prospect of stability". 76 Eban's view, based as he says only on intuition, was "that behind his [Hood's] maddening reticence there was now a tendency to accept our cause".77 What was really behind Hood's "maddening reticence" we will soon show.

Hood was also very critical of other members of the Committee for their criticism of the UK. "Some members, notably Yugoslavia, Uruguay and Guatemala, seemed to regard the Committee as a super Royal Commission charged with investigating and passing judgement on the history of the administration of the Mandatory." 78 Hood cited India, Canada and surprisingly enough, Yugoslavia, as supporting this critique. He considered that the view of the majority, "held most firmly by India, Canada and Australia, was that intervention in such matter was outside the competence and functions of the Committee".79

This was in line with Australian government support for Britain, even after Britain, following the tabling of the UNSCOP report, announced that it was withdrawing totally from Palestine. As Prime Minister Chifley said in the House of Representatives, "the UK government should no longer be expected to carry the burden of maintaining what was virtually a police force in Palestine". 80

The Australian delegation's guiding policies are stated clearly in the records of the Department of External Affairs where they were committed to "support the UK in general provided no fundamental conflict with Australian views". 81 Further, even if the UK should decide to agree to complete withdrawal from Palestine, "any plan for immediate transfer of power should be opposed on the ground that no solution is likely to please both Arabs and Jews and the risk of a violent reaction to an unpopular solution would be considerable". ${ }^{82}$ Thus, even though the Australians envisioned the possibility of Britain surrendering the Mandate, and even though they envisioned partition as the likely outcome, they did not favour the creation of two independent states, but the creation of two trusteeships, the "US over Jewish state and an Arab country over Arab Palestine". 83

This conviction about a trusteeship pre-dated Hood's service on UNSCOP and his Department's ostensible direction to arrive at a conclusion based on the facts and "to insist on a full enquiry into the facts and the law before any recommendation is submitted to a vote". 84 The Australians initially suggested that the "UK submit separate Trusteeships for an Arab and a Jewish portion of Palestine with large areas of self-government". ${ }^{85}$ The Australians believed that trusteeship was just the application of the Principles of the Charter which obliged the UK "to submit a Trusteeship agreement for Palestine with provision for early self-government and independence". ${ }^{86}$ The UN Australian delegation on 29 August was committed to "accept trusteeship in the interim". ${ }^{87}$ However, the Australian delegation received a report on 28 October 1947 which was pessimistic concerning trusteeship based on the fruitless failure of UN military staff committees.

The Australian position even went beyond that of the UK when it came to their pro-Arab stand. On 18 April 1947 the UN delegation registered their conviction that an 
Arab state should have been a member of UNSCOP. "There should be representation of members acceptable to the Palestinian Arabs and Jews, e.g., an Arab League Member [Egypt or Syria was suggested] and the United States." 88 Why did they hold this view? Did their belief that they were winning favour with the Arab states have anything to do with it? "We are one of the few Delegations to retain the confidence and goodwill of Arab States which will be useful in September."89 Useful for what in September? The explanation they gave publicly was that they were willing to consider the proposed Arab addition versus the UK because "Australia had always stood for a full and exhaustive investigation of all the facts before any decision was taken on the substance of matters arising in the United Nations" 90 But in their report for the autumn Session, they claimed that, "Justice and Australia's interests are most clearly allied to the Arab cause which demands a unitary state".91 Did that have anything to do with the fact that Evatt was campaigning hard to become President of the General Assembly?

Hood had explained his decision to abstain unless decisions were unanimous. That explanation, as far as I know, has never been challenged. ${ }^{92}$ But it doesn't make sense. Why had Hood been willing to sit on the subcommittee of UNSCOP dealing with boundaries when he knew partition would never be supported unanimously in the Committee? Was the principle of trusteeship and a pro-Arab conviction the real reason for the abstention? Why was it in Australia's interest to be pro-Arab? What use would winning favour with the Arabs be "in September"? How can we reconcile these pro-Arab convictions and opposition to an independent Jewish state with Hood's statement to the British, "that his country had supported partition all along"93 (emphasis added).

The explanation, I believe, is to be found in a self-serving desire to rewrite history when the real motives for the Australian policy on Palestine were a combination of the White Australia policy (the policy of restricting immigrants to Australia to those of European descent), of which both Evatt and Hood were strong defenders, and Evatt's personal ambition. In a report Hood wrote in preparation for the autumn Session of 1947 explaining the stand of the Australian delegation, he stated that respect for the principle of equal rights and self-determination of peoples as provided in Article 73 of the United States Charter where "peoples have not yet attained a full measure of self-government, recognize the principle that the interests of the inhabitants of those territories are paramount". 94 Evatt was the constitutional expert. He was directly responsible at San Francisco for the amendments to Article 73 making precisely this provision. ${ }^{95}$ The wording was Evatt's.

How did the Australian delegation interpret the provision? The UN would have to consult the population. "It also means that a solution which would force the inhabitants, against the will of the majority to accept any alteration in the constitution of its population should be opposed. In fact, from Australia's point of view there would be a narrow line between the United Nations attempting to impose upon the Palestinian Arabs an obligation to admit further Jewish immigrants and the United Nations attempting to open the doors of Australia to Asiatic immigration on the pretext that the failure to do so might endanger the peace and that the Australian immigration policy was contrary to the principle of the Charter in so far as it involved racial discrimination". 96 As Hood went on to write, the problem of Jewish DPs, "should not be solved at the expense of the Palestine Arabs and can only be solved by the co-operation of all member states".

It was the White Australia policy which dictated majority control on racial grounds against newcomers. The principle of racial discrimination was not to interfere in the domestic jurisdiction of a majority population. But if the situation in Palestine could not be solved except through partition, then it was critical that the community not be given independence, otherwise that independence would justify majority control over 
immigration. Trusteeship did not entail self-determination in the Evatt view, but only self-government. As quoted earlier, 97 "At UNCIO [United Nations Conference on International Organisation] Evatt gave two small indications of what would become his approach. The first was his refusal to go any further than self-government as the end goal of trustecship. The second was his insistence on no interference with the sovereignty of the countries to hold trusteeships." ${ }^{88}$ Hood's argument in his report directly reflected Evatt's legal conviction that even self-government was not entailed by trusteeship. "Even granting the Jewish claim that the Mandate is still in force and binding in International Law and that it supersedes all of the earlier United Kingdom promises, the Mandate does not oblige the Mandatory to safeguard the civil and religious rights of all the inhabitants and to introduce self-governing institutions." 99

Thus lack of sympathy for the Jews, the pro-UK outlook, the pro-Arab attitude and the self interest of Australia and its policy of preserving White Australia were all of a piece. This meant that the Australian delegation was pro-Arab and not pro-Zionist. Why then did Hood give the impression in the latter half of August of 1948 that he was pro-partition even though he never so declared himself? Why did Hood abstain and not vote for a unified federal state with the minority? Why in October 1947 did the Australian delegation reverse its stand and come out strongly in support of partition?

On 7 August 1947, Hood cabled to Canberra that "There is however no support for extreme claims for either side and very little support at this stage even for partition." 100 Possibly this was in response to an expression of fear that there was such support. The effect, however, was to arouse fears in Evatt that Hood would take a stand against partition. On 10 August 1947 the Minister cabled the Ambassador in Geneva - where the committee had retreated to write their report - to "Tell Hood at once that he should not at this stage take any line against partition of Palestine. He has never been authorised to do so and is there solely to report on events and not to [illegible] without prior official consultation with us. This is most urgent. I have had recent complaints of the attitude of one of the Australian representatives on the Palestinian Committee. They must be reminded that they are a fact finding body." 101

The Evatt line had been dictated to Hood. No stand at all. Why? And why did Hood not act as the independent delegate he was supposed to be? He tried. On 18 August 1947, with two wecks to go in the deadline to complete the report, Hood cabled External Affairs that "We have so far not taken any positive attitude in accordance with what I understand was the general sense of the Minister's wishes and also because of the complexity of the problem itself which has made it essential to give fair and careful examination to each in turn, of various solutions proposed". But Hood continued, "At the same time from now onwards it will become increasingly difficult for us to abstain from taking a position in respect to at least some final recommendations. There is no sign of any intention on part of most other members to refrain from committing themselves. On contrary many take view that more positive and explicit recommendations are made the better." 102

Hood also tried to say, in diplomatic language, of course, that Evatt's insistence that the Committee's mandate was to serve only as a fact finding body was just so much rubbish. "We fully understand the view of the Committee as primarily a fact-finding body, but having regard to the way in which Committee's work has developed, and also to the terms of reference from the special assembly it is not a practical question to exclude recommendations from the report." 103

But Hood, ever the loyal civil servant, then went on to say that he was making every effort to avoid committing the Australian delegation. "What we are trying to ensure is that the report will traverse fully all possible solutions with possibly an indication of preference in favour of one particular course, thus allowing the Assembly to be presented 
with a complete picture of the problem. Some members would wish to go further than this, and to present simply a single majority conclusion to Assembly, but I think this can be avoided. In any case we will naturally take every precaution to avoid any undesirable extent of Australlan commitment." 104

Hood then made clear where he wanted to make the commitment - not to vote for partition, but against. This was on 18 August. There "might after all be found to be no alternative but to impose a Trusteeship in Palestine with Palestinian self-Government as ultimate objective, we had a large measure of agreement from Netherlands, Indian and Iranian members". 105

Hood then requested that the decision be left to the delegation's discretion and suggested that partition with an economic confederation probably had majority support. "On present showing possibly a majority of some seven or eight will come down in favour of some such arrangement. I think our own attitude should be left to our discretion, in light of your G82 and of course proposed in paragraph 3 above [reference to taking precautions to avoid any undesirable extent of Australian commitment], but if you have any comments, we would appreciate receiving them at earliest possible moment, as we shall have to make our attitude clear in the very near future." 106 But Hood then immediately went on to say that discretion would imply abstention. "Our own idea if [sic] of what this attitude should be is that while assisting on presentation to Assembly of as clear and comprehensive a plan as possible for partition, plus confederation, we should leave our ultimate position open." 107

There were also objective grounds, or so Hood argued, to keep one's options open. Hood asked whether each entity would be considered sovereign and eligible for UN membership, "which is one of presumed objects of participation to secure"? He was sceptical whether any solution was politically feasible given Arab-Jewish animosity and the fact that no final judgement could be rendered until the attitudes of Arab states and other governments were made known in the Assembly. He noted the problem that if there was partition the Jewish State would be thirty-three per cent to fifty per cent Arab. ${ }^{108}$

The department, as well as everyone else on the Committee, now became baffled by Hood's equivocation. Give me the authority, but don't worry, I won't exercise it to embarrass the government. There is a majority in favour of partition with economic union, but I don't think it is workable, and am opposed to partition, but think I should abstain because I don't want to embarrass the Minister.

The department began a two-track policy. Keep a tight rein on Hood so he won't embarrass the Minister. Disown Hood as representing only his own views and not those of Australia. In a cable dated 21 August they instructed Hood, "You should avoid being associated with any recommendation which will embarrass the Minister later having been supported by his representative". ${ }^{109}$ At the same time they provided an outlet the very next day. "The Australian Govemment considers the Commission to be an independent body representing the assembly as a whole and that any particular course you may support is without commitment to the Government." 110

On 23 August 1947, Hood received definite instructions from the Department of External Affairs. "Most important we should not be committed to any recommendation." "Fact and alternative solutions and not recommendations should be included." 111 Hood cabled back the next day indicating a majority support for partition, his preference for the minority report for a federation, the impending pressure on Australia to make up its mind and his preference to do so, and then the important note that Hood and Atyeo had not yet committed themselves. India, Yugoslavia and Iran were the three other countries favouring a Federation. Sweden, Canada, Uruguay, Guatemala were for partition. There were now four votes to three for partition. Hood went on. "It will be necessary for us to 
decide within few days whether to take an attitude in favour of one or the other of alternative plans or whether to reserve our position until Assembly." "On balance our own feelings which we have not stated in committee is for Federation in preference to partition on grounds that by perpetuating Arab/Jewish antagonism partition will create as many problems as it solves."112 Hood could not have been clearer that he was opposed to partition, but he promised he would keep his position open in the meanwhile.

On 27 August 1947 the Middle East Section cabled Hood with definite orders. The terms of reference of UNSCOP were to "submit such proposals as it may consider appropriate for the solution of the problem of Palestine". Therefore, it was the "obligation on the Committee to go as far as Hood's suggestion in first sentence of paragraph 3 of UNSCOP 8", i.e. to present alternatives and present majority recommendations. Hood was not to vote, but if he voted, he was not to vote against partition. ${ }^{113}$ At the same time, the Department prepared a rationale for disowning Hood. "Although it is realised that there may be an element of embarrassment to the Minister if Hood supports a particular solution and the Minister subsequently wishes to support another, it may be considered that such an apparent change of front could be explained on the following basis - the special Committee does not solely represent the eleven Nations but represents all of the members of the Assembly which have delegated their task to it. As such the Committee is a body responsible to the Assembly to obtain and use impartially its specialised knowledge."114

The only position that would not embarrass Australia now was one that was pro-partition. "It does not appear that support for partition as the ultimate solution should be likely to embarrass Australia, so long as the recommended solution does not require an immediate transfer of power."115

Hood decided discretion was the better part of valour. On 28 August he provided two rationales for abstention. There was "no necessity to indicate now a preference for one proposed arrangement over another as the final determination could only be in the hands of the Assembly". Secondly, there was the issue of workability given all the political factors. 116

\section{The Autumn Session}

Hood and Evatt were for trusteeship, pro-Arab, pro the UK, but mostly pro a White Australia and the advancement of Evatt's political ambitions. The combination of factors inclined Hood to vote against partition and for a federation. Evatt was determined to keep his powder dry and his options open and prevailed upon Hood to abstain.

Why then did Australia reverse itself and come out in support of partition? First, Evatt was not elected as President of the General Assembly. This freed him from any immediate political factors determining his stand. Secondly, the UK decided to withdraw from the situation altogether; this removed the factor of Australian loyalty to the UK. Third, Australia, like the US and most other countries, was unwilling to intercede by providing their own volunteer forces to police a trusteeship.

On 1 October 1947 Prime Minister Chifley announced in the House of Representatives, in answer to a question from the opposition, that "no Australian troops will be sent to Palestine. Of that the honorable member can be completely confident; and in addition he can rest assured that we will be making no contribution to the work of the administration in Palestine."117 The Australians were still supporting the UK and supported the British decision not to blockade arms to the Arabs since Britain had to adhere to its treaty obligations, unless of course there was a UN resolution to that effect. 
Evatt's ambition had been thwarted. The UK had turned its back on the problem, and, increasingly they also turned their back on any responsibility to keep members informed. The British did not even have the grace to tell the truth. The Jews were clearly brave and determined. Finally, a two state solution would allow each state to restrict immigration or reinforce immigration from its own ethnic group, a position perfectly consistent with what would emerge as a dominant motif in both the Jewish, Arab and the general international relations community, but particularly in the USA.

Why then did Evatt end up supporting Israel and helping it achieve a two-thirds vote in the General Assembly for partition? The decision came near the very end of a long, gruelling session. By the time Australia jumped aboard, there was almost a two-thirds majority for partition. If Australia now voted against partition, Australia would have been alienated from almost two-thirds of the delegations. There were now more pro-Israel votes than pro-Arab votes. Australia voted for partition.

There is also the possibility that in the course of the debate, Evatt became convinced of the stronger arguments in favour of partition. But even then, the arguments were ones in support of a politically practicable solution rather than any principle of justice. Not even the principle of least injustice seemed to be the issue .

It was not justice or the awareness of Jewish suffering that impelled the Australian vote. It was expediency and practical politics. Principle did not provide the primary guides for Australian action. The principles and the policies that the Australians held dictated support for a unitary state. The Australians first abstained, even though they were pro-Arab, and then voted for partition when that was the prevailing direction in which the political winds were blowing and there were no longer any countervailing forces pushing in the other direction. 


\section{NOTES}

1 London: Kew Gardens, British Archives, Foreign Office (PO) 371/61771 E2764/46/31 and E2861/46/31 Cadogan, New York to FO, March 29th and April 2nd.

2 cf. Australian National Archives (henceforth ANA), File 852/20/2, Pt. 2. Ms Gillian Redmond of the Australian National Archives had not received my second letter specifying my exact date of arrival in Canberra. Virtually all of the files that I needed were still closed. Because I had travelled all the way from Canada, she and the staff of the ANA went out of their way to go through the files to make them accessible during my short stay. I am very grateful.

3 Herbert V. Evatt, The Task of Nations, (New York: Duel, Sloan and Pearce, 1949), p. 163.

4 Ibid., p. 168.

5 cf. Alan D. Crown, "The Initiatives and Influences in the Development of Australian Zionism, 1850-1948", Jewish Social Studies, 39, 4, (1977). Dr Rodney Gouttman, Abe Larda and Professor Julius Stone.

6 cf. W. D. Rubinstein. The Jews in Australia: A Thematic History. Vol. II: 1945-Present (Melbourne: Heinemann, 1991) and S. D. Rutland, The Edge of the Diaspora: Two Centuries of Jewish Settlement in Australia (Sydney: Collins Australia, 1988), both of whom depict Evatt in this way. I am grateful to Ms Barbara Dale of the Economic History Department, University of Sydney, for these references. Ms Dale and Professor Ken Buckley are co-authors of a forthcoming biography of Evatt. Evatt wrote a letter for a prominent Jewish business leader, Max Freilich of Sydney, author of Zion in Our Time (1969) whom he referred to as an individual he had known for years, permitting currency restrictions to be waived so that Freilich could transfer money to Israel. I am grateful to Barbara Dale for showing me this letter.

7 Peter Y. Medding, "Factors Influencing the Voting Behaviour of Melbourne Jews", in Peter Medding, ed., Jews in Australian Society, (South Melboume: Macmillan Company of Australia, 1973), p. 143.

8 Allan Dalziel, Evatt the Enigma, (Melbourne: Lansdowne Press, 1967), p. 59.

9 Evalt, The Task of Nations, p. 131.

10 Norman Harper and David Sissons, Australia and the United Nations, (New York: Manhattan Publishing Company, 1959), p. 278. Cf. Commonwealth of Australia, Parliamentary Debates, Vol. 196, 8 April 1948, p. 742.

11 Evath, The Task of Nations, p. 125.

12 Ibid., p. 133.

13 Dalziel, Evatt the Enigma, p. 9.

14 Kylie Tennant, Evatt: Politics and Justice, (Sydney: Angus and Robertson, 1970), pp. 236-7.

15 Alan Renouf, Let Justice Be Done: The Foreign Policy of Dr H. V. Evatt, (St Lucia: University of Queensiand Press, 1983), p. 246. Peter William Crockett has also written a PhD thesis for the History Department at La Trobe University in Melboume, H. V. Evatt: Character and Work, (1990). I was unable to examine the thesis, but I doubt if it could have dealt with the issue since virtually all the files at the Australian National Archives in Carberra had been closed until I examined them.

16 Creech-Jones gave this explanation to Lester Pearson. Canadian National Archives, Department of External Affairs Files, File 47B(s), CanDelUN to SSEA, February 21, 1948, no. 232. Cf. David J. Bercuson, Canada and the Birth of Israel: A Study in Canadian Foreign Policy, (Toronto: University of Toronto Press, 1985), p. 148.

17 Foreign Relations of the United States (FRUS), 1948, Vol. 5, Part 2, p. 564.

18 Abba Eban, An Autobiography, (New York: Random House, 1977), p. 146. There are, in fact, at least two possible factors to account for Evatt's strong support for the internationalisation of Jerusalem. The first is his obduracy in sticking to a decision once it was made, as he did with partition; and partition included an internationalised Jerusalem. The second is his attitude to the Catholic Church. "Dr. Evatt was always conscious of the political power of the Churches, and particularly of the Roman Catholic Church. He was often inclined to be over-anxious, a little too eager, to cultivate the Roman Catholic hierarchy." (Dalziel, Evalt the Enigma, p. 56.) "The Vatican had organized a strong agitation at the United Nations for the Holy City of Jerusalem to be put under some form of international control. This put Evatt in a very difficult position. 
Hailed by the Jews of Australia as one of their latter-day deliverers, he knew from their spokesmen in private that they looked with extreme disfavour on the Vatican proposal. Yet 1949 was general election year and Evatt realised that the Chifley Government would need every vote it could muster. The Roman Catholic hierarchy in Australia had taken up the Vatican's cry, and its leading members asked Evatt to support the scheme for the internationalisation of Jerusalem. Some of the Church of England and Free Church leaders added their weight to the Roman Catholic demands. Evatt assured the Roman Catholic bishops that Australia, at the United Nations, would support the Vatican's policy." (p. 60) Dalziel, Evatt's personal secretary for twenty years, weighs in on the side of political expediency rather than principle.

19 FRUS, 1948, Vol. I, No. 1, p. 495.

20 "That Australia intended to be more independent of Britain had been made apparent more by Curtin than by Evatt, but there was no difference between the two on that score, and as the war progressed, it would be Evatt who would pursue this strand of policy." Renouf, Let Justice Be Done, p. 92 .

21 Dalziel, Evatt the Enigma, pp. ix-x.

22 Eban, An Autobiography, p. 91.

23 Brian Urquhart, A Life in Peace and War, (New York: Harper \& Row, 1987), p. 96.

24 Ibid., p. 117. Evatt, as President of the General Assembly in autumn 1948, paid special tribute to the US representative, Eleanor Roosevelt, for playing a leading role in the victory of the Universal Declaration of Human Rights by 48 votes with 8 abstentions (GA II//, Plenary, p. 934), but regarded himself as a father of the UN Declaration. (Renouf, Let Justice Be Done) In his book, Task of Nations, he praises Eleanor Roosevelt as having, "earned her position by her own great merits, her own faith and enthusiasm for civil liberties and the advancement of the welfare of all mankind. Everywhere she went in France she was greeted with enthusiasm by the French people who would form themselves into crowds outside buildings that she was visiting" (p. 8). The United States, however, regarded Evatt as paranoid in another respect. "Evatt claimed that the United States had deliberately kept Australia off the sub-committee (dealing with the Atomic Energy Commission]. Mr. Ross (of the US delegation) believed this misunderstanding (emphasis added) should be corrected firmly." FRUS, 1948, I, 1, p. 460.

25 Israel State Archives, 90, 03/2266/15, letter from Michael Comay to Moshe Shertok, May 2, 1947; cf. also Wm. Roger Louis, The British Empire in the Middle East: 1945-1951: Arab Nationalism, The United States, and Postwar Imperialism, (Oxford: Clarendon Press, 1984), p. 490.

26 ANA, 852/20/2 Pt. 1. Bercuson, Canada and the Birth of Israel, goes too far when he declared unequivocally that Evatt, "clearly backed the UNSCOP majority proposals" p. 116.

27 Renouf, Let Justice Be Done, p. 247. Renouf cites as his source for Evatt's 1945 attitude A. D. Rothman's article, "Dr. Evatt and Israel", Nation, 6 May 1967, and a letter to the editor of the Nation from J. D. L. Hood and S. L. Atyeo, 17 June 1967.

28 Evatt, The Task of Nations, p. 131.

29 UNCIO Documents, Vol. XI, pp. 494-5.

30 Evatt, The Task of Nations, p. 60.

31 GAOR, 4th Sess., 1st Ctte., 297th Mtg., 26 Oct., 1949, p. 112.

32 Norman Harper and David Sissons, Australia and the United Nations, New York: Manhattan Publishing Company, 1959), p. 153.

33 New York, United Nations Archives, Minutes, United Nations General Assembly, seventyninth plenary meeting, May 15, 1947.

34 The Hague: Dutch Archives, Foreign Office, 999.212 UN/UNSCOP File 125, Nicolaas Blom Report to the Ministeire van Buitenlandse Zaken, 3 September 1947.

35 Dalziel, Evatt the Enigma, p. 31.

36 Renouf, Let Justice Be Done, p. 117.

37 On 27 December 1947, Britain's Prime Minister wrote Evatt an extraordinarily apologetic letter. "I am sorry if you formed the impression from the statements made by Cadogan and Martin during the New York discussions that we favoured the gradual assumption of functions in Palestine by the United Nations Commission ... Our conception of 'progressive' was 
geographical and not functional ... We came to the conclusion that even this form of piece-meal transfer was impossible." As the Prime Minister went on to explain, Britain wanted undivided control. (ANA, 852/20/2, Pt. 2. Great Britain refused to cooperate in any way in the transitional period leading up to independence, and in fact went back on assurances to Evatt that the government would allow a gradual takeover of the administrative apparatus in Palestine by a UN transitional team,

38 ANA, 852/19/2, Part 1.

39 'No one in [Canada's] cabinet spoke in favor of maintaining Canadian support for partition; the choice was between doing nothing and backing the 'temporary trusteeship' put forward by the United States." Bercuson, Canada and the Birth of Israel, p. 155.

40 ANA, 8521202, Pt. 2.

41 cf. W. J. Hudson, Australia and the Colonial Question at the United Nations, (Sydney: Sydney University Press, 1970), pp. 22-30. Australia's original draft proposal was short on rigour and depended on the territory being submitted to UN jurisdiction or where "appropriate action" was taken by the UN (which Australia interpreted as universal de facto jurisdiction for the UN). As a precedent for UNSCOP, Evatt envisioned an expert body that would hear the reports of a colonial power and make recommendations (with no suggestion that unanimity was required) as part of their report to the United Nations.

42 Renouf, Let Justice Be Done, p. 248.

43 Evatt had asked the British to approach the Americans to get their support. (FRUS, 1948, I, 1, p. 114.) Urquhart went even further in his claims about Evatt's ambition. "Dr. Evatt had wished to become Secretary-General, first President of the General Assembly, and a Judge of the International Court, but in casting too wide a net had missed them all." (Urquhart, $A$ Life in Peace and War, p. 96.) Of course, he did win the Presidency, as Urquhart knew, in autumn 1948. Urquhart describes a hilarious scene in which, after a furious fight between Evatt and Lie, Lie slammed the door on Evatt's partitioned office and caused the partitions to collapse (p. 117). In fact, Evatt won the Presidency, not because of wide support, but because of the absence of a suitable rival. For example, the Americans in a note from Jessup, Acting United States Representative at the United Nations to the Secretary of State (September 7, 1948) recommended that the US make the "best of a bad bargain" (FRUS, 1948, I, I, p. 128) and George Marshall agreed that, "in absence of strong altemative candidate, Dept. would be disposed to vote for Evatt but would not wish to campaign for him or for anybody else" (FRUS, 1948, I, l, p. 120). Lester Pearson, who was Deputy Minister for Extemal Affairs, and became Minister of External Affairs on 10 September 1948, "had serious reservations" about Evatt (FRUS, 1948, I, l, p. 121).

44 ANA, 852/20/2 Pt. 2.

45 FRUS, 1948, vol. 5, pp. 987-988.

46 lbid.

47 ANA, 852/19/1

48 Ibid.

49 Ibid.

50 Evatt, The Task of Nations, p. 125.

51 Bercuson, Canada and the Birth of Israel, p. 78.

52 London: Kew Gardens, FO. 371, Ref. 67586, File 2593.

53 The evidence for this is contained in a forthcoming article of mine based on access to Dutch archives in The Hague which had not previously been opened. The material will also be included in my forthcoming book, The United Nations and the Birth of Israel. The clearest statement of the Dutch delegation's concem not to alienate the Arabs by taking any stand directly and clearly opposed to the Arab position lest the Arabs oppose the Dutch position in Indonesia, emerges from Bloom and Spitz themselves, the Dutch delegates to UNSCOP, in their 28 May 1947 memo to the Foreign Office. "In het gesprek heb ik ten allen ovenvloede nog eens doen witkomen, dathet met het oog op Nederlandsch-Indie in het algemeeng ewenstzal zijn te vermijden, dat van Nederlandse zijde te sterk tegenoven de Arabieren stelling wordt genomen."

54 cf. ANA, 852/20/2 Pt. 1. 
55 "The Netherlands quickly came to regard him [Evatt] as hostile to its interests." Renouf, Let Justice Be Done, p. 160. For that reason, the Dutch would not support Evatt's candidacy for President of the UN General Assembly (FRUS, 1948, I, 1, p. 130). Renouf goes on to explain that, "whereas in reality he [Evatt] was the member of the government most responsive to those interests, not out of sympathy for the Netherlands but because of the use to which its interests might be put to further Australia's own interests".

Bercuson, Canada and the Birth of Israel, p. 78.

57 ANA, FA A2937.

58 ANA, FA A2737.

59 ANA, T45/518. Atyeo was a very close personal friend of Evatt's; their wives, who were both artists, were also close friends. I am indebted to Ms Barbara Dale of the Economic History Department of the University of Sydney for this information. She and her co-author, Professor Ken Buckley, are undertaking research on a forthcoming biography of Dr H. V. Evatt.

60 Tennant, Evatt: Politics and Justice, p. 183.

61 ANA, 852/20/2 Pt. 1.

62 ANA, A/1838/1 1500/2/21/1.

63 Eban, An Autobiography. p. 77.

64 ANA, 852/20/2 Pt. 1, May 14, 1947.

65 Tennant, Evatt: Politics and Justice, p. 180.

66 ANA, April 18/47, 852/19/1.

67 Canadian Archives, Ottawa, DEA files, file 5475-CD-40c, SSEA to Canadian Ambassador, in Washington, May 9, 1947 quoted in Bercuson, Canada and the Birth of Israel, p. 70.

68 Canada, Hansard, June 2, 1947, 3708 (Bercuson, Canada and the Birth of Israel, p. 77).

69 ANA, 852/20/2 Pt. 1.

70 Before Bloom cast a vote on the Special Committec, he said he would seek the instructions of the Minister. "Ik heb nu mett Mr. Bloom afgesproken, dat hij zonder instructies naar New York vertrekt en dat hij, wanneer de beraadslagingen in de Commissie in een stadium komen, dat hij zich moet uitsspreklen, hij de Minister zal mededelen welk standpunt hij sou willen innemen en dan dienaangaande instructies zal vragen". The Hague: Dutch Archives, 28 May 1947.

71 ANA, 852/20/2 Pt. 1.

72 After the Arab motion calling for immediate independence and termination of the mandate was defeated, and even though they opposed setting up UNSCOP, the Arabs claimed the right to have one member on the committee .

73 Bloom (and Spitz) not only opposed visiting the DP camps in Europe, but they argued that such visits were entirely unnecessary to fulfil the functions of UNSCOP. Bloom and Spitz went much further than Hood for they even opposed the right of the Jewish Agency to make representations before UNSCOP or the UN. The Dutch delegation opposed giving the Jewish Agency a right to speak in the General Assembly using the argument that it would "set a precedent". (Dutch Archives, The Hague, Minutes, Dutch delegation, 1 May 1947.) When, according to their own reflections, justice combined with opportunism led to the defeat of their position on the Jewish Agency, they worked to restrict the range of matter on which the Jewish Agency could speak. They ardently opposed allowing Jewish Zionist organisations the right to speak. They seemed to identify the Jewish penetration of Palestine with communist infiltration. (ibid., Minutes, Dutch delegation, 3 May 1947).

74 cf. Bercuson, Canada and the Birth of Israel, p. 92.

75 Eban, An Autobiography, p. 83.

76 ANA, 852/20/2 Pt. 1.

77 Eban, An Autobiography, p. 83.

78 ANA, 852/20/2 Pt. 1.

79 June 23/47 cabled June 30, ANA, 852/20/2 Pt. 1.

80 House of Representatives Proceedings, Sept. 30, 1947.

81 ANA, 852/20/2 Pt. 1.

82 Ibid.

83 Ibid.

84 ANA, 852/20/2 Pt. 1. 
85 ANA, April 18/47, 852/19/1.

86 ANA, 852/20/2 Pt. 1, report for the autumn session.

87 ANA, 852/20/2 Pt. 1.

88 ANA, 852/19/1.

89 ANA, April 22/47, 852/19/1.

90 ANA, May/47, 852/19/1.

91 ANA, 852/20/2 Pt. 1.

92 cf. Bercuson, Canada and the Birth of Israel, p. 105.

93 lbid., p. 215.

94 ANA, 852/20/2 Pt. 1.

95 cf. Renouf, Let Justice Be Done (1983), p. 233.

96 ANA, File 852/20/2 Pt. 1., p. 18.

97 cf. Dalziel, Evatt the Enigma, pp. ix-x.

98 Renouf, Let Justice Be Done, p. 248.

99 ANA, 852/20/2 Pt. 1, pp. 10-11.

100 ANA, 852/20/2 Pt. 1.

101 ANA, 852/20/2 Pt. 1.

102 Ibid.

103 Ibid.

104 lbid.

$105 \mathrm{Ibid}$. So much for Eban's intuitions. So much for historians concluding that Hood was pro-partition because he sat on the sub-committee boundary committee. Bercuson concluded on 6 August 1947 that "Hood and Blom pronounced themselves in favour of partition" (Canada and the Birth of Israel, p. 95). The minutes provide no support for such a definitive statement. The External Affairs department cables indicate quite the reverse.

106 Ibid.

107 Ibid.

108 Ibid.

109 Ibid.

$110 \mathrm{Ibid}$.

111 lbid.

112 lbid.

113 Ibid.

114 Ibid.

115 Ibid.

116 Ibid.

117 ANA, 852/20/2 Pt. 1. 